\title{
$\mathrm{SO}_{2}+\mathrm{MgSO}_{4}$ 二成分蒸解法に関する研究 カラマツ・アカマツからのケミカルパ ルプ製造と蒸解廃液からの $\mathrm{MgSO}_{4}$ 回収」
}

\author{
北海道大学工学部 鈴 木 勉, 戸 坂 图 夫, 林

\section{Studies on $\mathrm{SO}_{2}$ and $\mathrm{MgSO}_{4}$ Cooking Chemical Cooking of Larch and Red-pine, and Recovery of $\mathrm{MgSO}_{4}$ from Cooking Waste Liquor}

治 助

\author{
Tutomu Suzuki, Kunio Tosaka and Jisuke Hayashi \\ Department Applied Chemistry, Faculty of Engineering, Hokkaido University
}

Larch and red-pine chips, which were composed of sap-and heart wood by equal weight, were cooked in the liquor of $32 \% \mathrm{SO}_{2}$ and $24 \% \mathrm{MgSO}_{4}$ the same cocentration as in the chemical pulping of spruce and it has been examined whether the quality of the pulps is good or not.

The relationship between cooking temperature and time to obtain chemicalpulp from larch or red-pine were 6,4 , and $3 \mathrm{hrs}$. at the temperatures of $135^{\circ}$ to $140^{\circ}, 150^{\circ}$, and $160^{\circ} \mathrm{C}$, respectively.

All these pulps contained the considerable amount of screenings of 10 to $20 \%$ by weight based on an ovendry wood, but they were easily defiberated with Disc-refiner.

Screened yield and paper strength of the pulps obtained from larch or red-pine at $135^{\circ}$ to $140^{\circ} \mathrm{C}$ were comparable or superior to those of $\mathrm{Mg}$-base sulfite pulps.

When cookings of these species were carried out with the same temperature-time schedule as in the sulfite, so-called easy-bleaching type, screening yields of pulps became higher and also reject stocks were significantly reduced.

The pulps showed excellent paper strength comparable to KP, and furthermore the yield of fiber stock was superior to that of KP.

The recovery of $\mathrm{MgSO}_{4}$ as a cooking chemical from waste liquors of softwoods was investigated.

The recovery was not dependent on the type of waste liquor but on the degree of carbonization of waste liquors by evaporation.

The chemicals was completely separated from highly carbonized substance by washing with water.

However, in low degree of carbonization, the two-steps washing with $\mathrm{SO}_{2}$ solution and water was required for the full separation of the chemical.

\section{1. 緒 言}

カラマツ・アカマツなどマツ類の心材は, $\mathrm{Ca}$ ベー スサフルァイト法では蒸解困難であり, その原因は心 材に含まれるフェノール成分がスルホン化を妨害する 1)2) ほかに，薬液の浸透が困難であるためと言われる。 しかし現在までには, $\mathrm{Na}$ や $\mathrm{Mg}$ などの可溶性べー
ス，中性やバイサルファイト二段蒸解法が開発改良さ れて,これらマツ類からでも比較的良質のパルプが得 られることが報告されている ${ }^{3) \sim 13) 。 ~}$ $\mathrm{SO}_{2}+\mathrm{MgSO}_{4}$ 二成分蒸解法は一種の 可溶性ベース 法と考えられるが, これらの樹種の蒸解はまだ行って いないので，高収率でしかも紙力の高いケミカルパル プが得られるかどらかについては興味が持たれる。そ 
Table 2 Chemical Components of red pine (\%)

\begin{tabular}{|c|c|}
\hline Alcohol-Benzene extract & 2.91 \\
\hline Holocellulose & 66.4 \\
\hline$\alpha-$ Cellulose & 36.1 \\
\hline Pentosan & 10.8 \\
\hline Lignin & 27.2 \\
\hline
\end{tabular}

こで先に行ったエゾマツの蒸解条件 ${ }^{14}$ に基づいて, カ ラマツ・アカマツの心材辺 1 , 材 1 対混合チップを蒸 解した結果を報告する。

この二成分蒸解法は, 用いた薬品の完全回収を目的 と寸る方法である ${ }^{15)}$ 。蒸解廃液から薬品を回収し, 廃 液中の木材有機成分を利用することは，パルプの製造 コストを下げ，無公害化にもつながって，蒸解法を工 業的に確立させるための必要条件である。我々の研究 室では, 数年前から二成分廃液中の有機成分の利用法 として活性炭の製造を試みている ${ }^{16)}$ が，この行程で， 残存する $\mathrm{SO}_{2}$ や $\mathrm{MgSO}_{4}$ を回収出来る見通しを持って いる。そこで上記のカラマツとアカマツ，そして先の エゾマツの廃液から，薬品を定量的に回収できるかど らかについても検討してみた。なお, $\mathrm{SO}_{2}$ は廃液を加 熱漕縮する際にガス化し，これを低温の水に通すこと によって容易に回收できると考えられるので，ここで は行っていない。

\section{2. 実験方法}

\section{1 カラマツとアカマツの蒸解}

\section{1 .1 試料之前処理}

風乾状態でそれぞれ $11.7 \%$ ，11.5\% のカラマッ・ アカマツの心材と辺材 $1: 1$ 混合チップを絶乾量で $200 \mathrm{~g}$ 採取し, 前処理として $2 l$ 容ビーカー中で 1 時 間水㐗沸した。

これら 混合チップの 化学的成分組成を Table 1,

Table 2 に示した。

\section{1 .2 蒸解液の調製と薬品量の表示}

蒸解薬品は $\mathrm{SO}_{2}$ 水と $\mathrm{MgSO}_{4}$ である。 $\mathrm{SO}_{2}$ 水は, $10 l$ 容試薬瓶に蒸留水を約 $8 l$ 入れて, ボンベから $\mathrm{SO}_{2}$ ガスを導入して $\mathrm{SO}_{2}$ 濃度 $8 \sim 10 \mathrm{~g} / 100 \mathrm{cc}$ となる ように調製したものを用いた。 $\mathrm{MgSO}_{4}$ は市販の 1 級 品・ 7 水塩を用いた。

これらを $\mathrm{SO}_{2} 32 \%, \mathrm{MgSO}_{4} 24 \%$ (対絶乾木材重 量）になるように採り，蒸留水を加えて全量が 1,000 $\mathrm{m} l$ の蒸解液を調製した。

\section{1 .3 蒸 解}

Table 1 Chemical Components of larch (\%)

\begin{tabular}{|lc|}
\hline Alcohol-Benzene extract & 3.82 \\
Holocellulose & 68.2 \\
\&-Cellulose & 35.9 \\
Pentosan & 8.3 \\
Lignin & 26.3 \\
\hline
\end{tabular}

前処理後のチップを $3 l$ 容オートクレーブに入れ， 蒸解液を加えてオイルバスに浸漬し, オイルバスが 1 時間で目的の温度に到達するように加熱して，所定時 間保持した。

蒸解終了後水中に投入して急冷し，パルプを取り出 し，これを布袋に入れて水洗した。

\section{1 .4 パルプ収率とスクリーン処理}

水洗後のパルプをディスインテグレーターで蒸解し， 8 カットスクリーンを通して繊維部とスクリーン粕と を分離してから，それぞれの全体重量と水分率を測定

し, 絶乾量を求めて収率を計算した。 収率は, 処理木材重量に対する值（\%)である。

\subsection{5 ディスクリファイナー処理}

スクリーン粕が多量であった場合，これをワルドロ ン・シングルディスクリファイナーで解繊した。

解織は, 次のような一定の条件で行った。

・試料送入量 $\quad 70 \sim 80 \mathrm{~g} / \mathrm{min}$.

·水送入量 $\quad 7 \mathrm{l} / \mathrm{min}$.

・クリアランス $1 / 48$ inch.

・解瀻回数 $1 \sim 2$ 回

\subsection{6 成分分析 $\cdot$ 白色度 $\cdot$ 紙力試験}

蒸解パルプは精製瀻維と解瀻瀻維を合わせたものと し，解織部が精製部の $10 \%$ を越えるものでは，それ ぞれの収率に見合う割合で両者を混ぜて以下の試験に 供した。

a) 成分分析

パルプをディスインテグレーターで離解し, 標準抄 紙器で適当な厚さに抄紙して風乾したシートを0.5 $0.6 \mathrm{~cm}^{2}$ の小片に切り, これを標準分析法 ${ }^{17}$ に使って 分析した。

b)白色度

JIS 法 ${ }^{18}$ に従い, ハンター白色度部を用いて測定し た。

c）紙力試験

パルプをホランダー型ビーターで吒解し，カナディ アンフリーネステスターによるフリーネスが $400 \pm 20$ ccとなったものを Tappi 標準法敫によって抄紙し， 
これを $25^{\circ} \mathrm{C}$, 湿度 $65 \%$ のデシケーターに一昼液放置 後, JIS 法 ${ }^{20)}$ 亿従って引偯り, 破裂, 引裂きの各強度 を測定し, 裂断長, 比破裂強さ, 比引裂強さを求めた。

\section{2 蒸解廃液からの $\mathrm{MgSO}_{4}$ 回収試験}

ヌッツェ上に沪紙を敷き, 败引して蒸解パルプと廃 液を分離した。この廃液の一部を採り, 常法にしたが って $\mathrm{BaCl}_{2}$ 水溶液を加え, 生成した $\mathrm{BaSO}_{4}$ の沈殿 量からあらかじめ廃液中の $\mathrm{MgSO}_{4}$ 量を求めておいた。 残りの廃液を $1 l$ の武薬瓶に入れ, アスピレーターで 吸引しながら空気を送り込み, $\mathrm{SO}_{2}$ の臭気がなくなる まで脱 $\mathrm{SO}_{2}$ を行った。次に $200 \mathrm{cc}$ の磁製蒸発血に 少量ずつ移しながら, 晹浴上で蒸発乾固させ, $105^{\circ} \mathrm{C}$ で恒量となった重勧を测定した。この乾固物の所定量 を $100 \mathrm{cc}$ 容の磁製るつぼに採り, 後述の条件で有機 物の炭化を行った。炭化終了後, 残留物を放冷するこ となく $200 \mathrm{cc}$ の蒸留水中に投入し, 目血付きロート に汇紙を敷いて吸引しながら熱水洗浄を行い, $500 \mathrm{cc}$ の洗浄液を得た。さらに必要がある場合には，1\%の $\mathrm{SO}_{2}$ 水で洗浄をくり返した。この後, 残留炭化物の 絶乾量を測定して収率（炭化洗浄後の重量/採取量 $\times$ 100）を計算し，また洗浄液の一部についてキレート 滴定を行い, $\mathrm{Mg}^{2+}$ の量から $\mathrm{MgSO}_{4}$ としての值を求 めて先の測定值と比較した。

\section{3. 結果と考察}

\section{1 カラマツとアカマツの蒸解}

木材の蒸解反応速度は, 一般の化学反応と同様仅反 応温度と時間, 薬品量に依存する。しかし, 蒸解パル
Table 3 The Relationship between Cooking Temperature and Time to obtain chemical pulp from larch as well as red pine.

\begin{tabular}{|c|c|c|c|c|c|}
\hline$\underset{\left.{ }^{\circ} \mathrm{C}\right)}{T_{(\mathrm{hr})}}$ & 2 & 3 & 4 & 5 & 6 \\
\hline 135 & - & $x$ & $x$ & $\Delta$ & 0 \\
\hline 140 & - & $x$ & $x$ & $\Delta$ & 0 \\
\hline 150 & - & $\Delta$ & 0 & 0 & - \\
\hline 160 & $\Delta$ & 0 & 0 & - & - \\
\hline
\end{tabular}

$\bigcirc$ soft cooked, $\Delta$ semi-hard cooked, $\times$ hard cooked.

プの品質は, 薬品量よりはむしろ温度と時間に大きく 影響されるよらである。そこで，エゾマツを蒸解した 時に比較的良質のケミカルパルプが得られた薬品量, $\mathrm{SO}_{2} 32 \%+\mathrm{MgSO}_{4} 24 \%$ の蒸解液を用いて, 蒸解温度 を $135^{\circ} \mathrm{C}, 140^{\circ} \mathrm{C}, 150^{\circ} \mathrm{C}, 160^{\circ} \mathrm{C}$ と変えてカラマッ. アカマツを蒸解した。

Table 3 には, カラマツの蒸解においてケミカル パルプが得られた温度と時間の関係を示した。Table 中の○印がケミカル蒸解であったことを示す。

蒸解温度 $135^{\circ} \mathrm{C}$ から $140^{\circ} \mathrm{C}$ の場合, 5 時間では心 材部分がまだ固く，6時間で全体的に柔らかくなった。 $150^{\circ} \mathrm{C}, 160^{\circ} \mathrm{C}$ の温度では, それぞれ 4 時間, 3 時間 でケミカルパルプが得られたが，辺材に比べて心材の

Table 4 Cooking Conditions of Kraft and Mg-base Sulfite.

Kraft

Amount of Chemicals; active alkali $25 \%$ on an ovendry wood and Sulfidity $25 \%$

Temp. and Time; $\quad$ room temp. $\underset{1 \mathrm{hr} .}{\longrightarrow} 170,{ }^{\circ} \mathrm{C} \underset{2 \mathrm{hrs} .}{\longrightarrow} 170^{\circ} \mathrm{C}$

Liquid to wood ratio; $1,000 \mathrm{~m} l / 200 \mathrm{~g}=5$

$\mathrm{Mg}$-base Sulfite

Amount of Chemicals; Total $\mathrm{SO}_{2} 6 \%$ and Comb. $\mathrm{SO}_{2} 1 \%$ in the liquor.

Temp. and Time;

$$
\begin{aligned}
& \text { a) room temp. } \underset{1 \mathrm{hr} .}{\longrightarrow} 150^{\circ} \mathrm{C} \underset{4 \mathrm{hrs} .}{\longrightarrow} 150^{\circ} \mathrm{C} \\
& \text { b) room temp. } \underset{1 \mathrm{hr} .}{\longrightarrow} 110^{\circ} \mathrm{C} \underset{4 \mathrm{hrs} .}{\longrightarrow} 110^{\circ} \mathrm{C} \underset{1 \mathrm{hr} .}{\longrightarrow} 150^{\circ} \mathrm{C} \underset{4 \mathrm{hrs} .}{\stackrel{\longrightarrow}{\longrightarrow}} 150^{\circ} \mathrm{C}
\end{aligned}
$$

Liquid to wood ratio; $1,000 \mathrm{~m} l / 200 \mathrm{~g}=5$ 
Table 5 Yields and properties of pulps obtained by various temperature-time cookings of larch

\begin{tabular}{|c|c|c|c|c|c|c|c|c|c|c|}
\hline \multicolumn{2}{|c|}{ Conditions } & \multirow{2}{*}{$\begin{array}{c}\text { Total } \\
\text { yield } \\
(\%)\end{array}$} & \multirow{2}{*}{$\begin{array}{c}\text { Screened } \\
\text { yield } \\
(\%)\end{array}$} & \multicolumn{3}{|c|}{ Chemical Components (\%) } & \multirow{2}{*}{$\begin{array}{l}\text { Bright- } \\
\text { ness }\end{array}$} & \multicolumn{3}{|c|}{ Paper Strength } \\
\hline $\begin{array}{c}\text { Temp. } \\
\left({ }^{\circ} \mathrm{C}\right)\end{array}$ & $\begin{array}{l}\text { Time } \\
\text { (hr.) }\end{array}$ & & & $\begin{array}{l}\text { Holo- } \\
\text { cellulose }\end{array}$ & Pentosan & Lignin & & $\begin{array}{l}\text { Breaking- } \\
\text { length }(\mathrm{km})\end{array}$ & $\begin{array}{l}\text { Burst } \\
\text { factor }\end{array}$ & $\begin{array}{l}\text { Tear } \\
\text { factor }\end{array}$ \\
\hline 135 & 6 & 66.5 & 44.6 & 80.3 & 5.5 & 18.2 & 22.4 & 4.4 & 2.4 & 48 \\
\hline 140 & 6 & 64.6 & 45.3 & 81.3 & 4.5 & 16.4 & 22.7 & 4.6 & 2.5 & 49 \\
\hline 150 & 4 & 60.2 & 39.3 & 80.5 & 4.2 & 17.9 & 19.5 & 3.6 & 1.8 & 49 \\
\hline 150 & 5 & 53.9 & 41.3 & 86.4 & 3.7 & 12.1 & 19.8 & 3.8 & 2.0 & 52 \\
\hline 160 & 3 & 57.9 & 35.5 & 80.6 & 3.8 & 18.5 & 21.2 & 3.5 & 1.9 & 49 \\
\hline 160 & 4 & 52.1 & 38.5 & 87.9 & 4.1 & 10.3 & 22.6 & 3.6 & 2.0 & 52 \\
\hline \multicolumn{2}{|c|}{$\mathrm{Mg}$-base SP a ) } & 55.8 & 44.9 & 91.6 & 5.1 & 7.7 & 34.8 & 3.8 & 2.0 & 46 \\
\hline & b) & 51.2 & 46.9 & 93.8 & 3.7 & 5.4 & 34.5 & 3.6 & 1.9 & 49 \\
\hline \multicolumn{2}{|l|}{$\mathrm{KP}$} & 42.3 & 42.2 & 97.3 & 8.2 & 2.3 & 25.2 & 6.1 & 3.4 & 90 \\
\hline
\end{tabular}

Table 6 Yields and properties of pulps obtained by various temperature-time cookings of red pine

\begin{tabular}{|c|c|c|c|c|c|c|c|c|c|c|}
\hline \multicolumn{2}{|c|}{ Conditions } & \multirow{2}{*}{$\begin{array}{c}\text { Total } \\
\text { yield } \\
(\%)\end{array}$} & \multirow{2}{*}{$\begin{array}{l}\text { Screened } \\
\text { yield } \\
(\%)\end{array}$} & \multicolumn{3}{|c|}{ Chemical Components (\%) } & \multirow{2}{*}{$\begin{array}{l}\text { Bright- } \\
\text { ness }\end{array}$} & \multicolumn{3}{|c|}{ Paper Strength } \\
\hline $\begin{array}{c}\text { Temp. } \\
\left({ }^{\circ} \mathrm{C}\right)\end{array}$ & $\begin{array}{l}\text { Time } \\
\text { (hr.) }\end{array}$ & & & $\begin{array}{l}\text { Holo- } \\
\text { cellulose }\end{array}$ & Pentosan & Lignin & & $\begin{array}{l}\text { Breaking- } \\
\text { length }(\mathrm{km})\end{array}$ & $\begin{array}{l}\text { Burst } \\
\text { factor }\end{array}$ & $\begin{array}{l}\text { Tear } \\
\text { factor }\end{array}$ \\
\hline 135 & 6 & 64.8 & 45.3 & 80.3 & 5.9 & 18.9 & 27.4 & 4.5 & 2.2 & 57 \\
\hline 140 & 6 & 61.0 & 43.9 & 80.6 & 5.3 & 18.3 & 31.9 & 4.9 & 2.3 & 59 \\
\hline 150 & 4 & 58.5 & 39.9 & 82.5 & 4.9 & 16.9 & 24.0 & 3.6 & 1.7 & 54 \\
\hline 150 & 5 & 50.0 & 40.9 & 86.5 & 3.9 & 12.8 & 28.5 & 4.3 & 1.9 & 58 \\
\hline 160 & 3 & 54.6 & 37.8 & 85.7 & 4.1 & 8.7 & 26.7 & 3.5 & 1.5 & 52 \\
\hline 160 & 4 & 50.2 & 39.4 & 89.9 & 3.8 & 8.9 & 25.8 & 3.8 & 1.8 & 57 \\
\hline \multicolumn{2}{|c|}{$\mathrm{Mg}$-base $\mathrm{SP}$ a) } & 54.7 & 44.2 & 90.7 & 5.3 & 7.9 & 42.8 & 3.9 & 1.9 & 51 \\
\hline & b) & 50.1 & 47.4 & 95.4 & 3.7 & 4.0 & 45.2 & 3.8 & 1.8 & 55 \\
\hline \multicolumn{2}{|l|}{ KP } & 42.8 & 42.6 & 96.2 & 8.7 & 3.1 & 26.2 & 6.3 & 3.5 & 87 \\
\hline
\end{tabular}

蒸解度は低いようであった。これらの温度で蒸解時間 を 1 時間延長すると, 心材も十分にパルプ化されてい た。

アカマツの蒸解でも，Table 3 と同様な結果であっ た。

Table 5 にカラマツ, Table 6 にアカマツのケミカ ルパルプについての収率, 化学的成分組成, 白色度,

紙力を示した。なお比較のために, Table 4 の条件で 行った $\mathrm{Mg}$ ベースサルファイト法, クラフト法の結 果も付記した。

Table 5 のカラマツの場合, $135^{\circ} \mathrm{C}$ と $140^{\circ} \mathrm{C}$ の 6 時 間パルプの全収率はそれぞれ $66.5 \%, 64.6 \%$ とセミ
ケミカル並みの值で, 8 カットスクリーンを通過した 精製繊維収率は $44.6 \%$ ，45.3\% であった。したがっ て全収率から精製収率を引いたスクリーン粕は $21.9 \%$, $19.3 \%$ と高く，心材の繊維分離の程度は低いもので あった。 $150^{\circ} \mathrm{C}-4$ 時間, $160^{\circ} \mathrm{C}-3$ 時間では, 全収率 がそれぞれ 60.2，57.9\%，精製収率が 39.3，35.3\% であった。全収率は $135^{\circ} \mathrm{C}, 140^{\circ} \mathrm{C}$ パルプよりも低下 しているが, 精製収率も低下しており,これらの条件 でも辺材は十分に繊維化しているが，心材は不十分で あった。 $150^{\circ} \mathrm{C}-5$ 時間, $160^{\circ} \mathrm{C}-4$ 時間では, $53.9 \%$, $52.1 \%$ 全収率であり 1 時間の蒸解延長で全体として の蒸解度は向上したが，精製収率は $41.3 \% ， 38.5 \%$ 
とそれぞれの増加は $2.0 \%, 3.0 \%$ なので全収率の減 少值よりも小さかった。このことは, 心材の瀻維化が 進むより, 主として辺材のパルプ化繊維の損失が大き いことを示している。

このように, Table に示したパルプはいずれもスク リーン残査が多かったが，これらのものは手による解 織が可能なほど柔らかくパルプとしても十分使用でき ると考えられたので, ディスクリファイナーで軽く解 繊し, 2.1.6 で述べたように精製繊維に加えて成分分 析, 白色度, 紙力試験を行った。

パルプ中のリグニンとペントサンについてみてみる と, $135^{\circ} \mathrm{C}$ と $140^{\circ} \mathrm{C}$ のパルプは低蒸解度で解繊繊維量 が多いために, リグニンは $18.2 \%, 16.4 \%$ と高い值 であり, ペントサンも $5.5,4.5 \%$ と一連のパルプの うちでは高かった。これらのパルプより， $150^{\circ} \mathrm{C}-4$ 時間, $160^{\circ} \mathrm{C}-3$ 時間では収率が低いにもかかわらず リグニン量は依然として高く，17.9\%，18.5\% であ った。これは, 解繊繊維が減少せず,むしろ全体に対 する寄与程度が高いためであろら。これらの温度で, それぞれ 5 時間, 4 時間蒸解すると, リグニン量は低 下して $12.1 \%$ ，10.3\% となった。一方ペントサンは $3.7 \% ， 4.1 \%$ を示し，前者は 4 時間よりも僅かに減 少したが後者では 3 時間よりも増加していた。すなわ ち収率の低下から考えると， $150^{\circ} \mathrm{C}, 160^{\circ} \mathrm{C}$ ともにこ の延長期間では脱ペントサンよりも脱リグニンの方が 優先的に進行し, パルプ化の状況としては好ましかっ たと判断される。

しかし, $150^{\circ} \mathrm{C} \sim 160^{\circ} \mathrm{C}$ で得られるパルプの 紙力は, 蒸解の程度やリグニンとペントサンの溶出選択性に影 響されず，裂断長が 3.5 3.8，比破裂強さが $1.8 \sim$ 2.0, 比引裂強さが 49〜52 とほとんど 変化がなかっ た。これに対して $135 \sim 140^{\circ} \mathrm{C}$ のパルプは, 裂断長 $4.4,4.6$, 比破裂強さ $2.4,2.5$, 比引裂強さ 48,49 であり, 裂断長, 比破裂強さでは $150 \sim 160^{\circ} \mathrm{C}$ パルプ よりも優れており, 蒸解度の低さはやはり紙力に不利 とはなっていなかった。

白色度は, 通常の測定では 19.5 22.7 と低い值で あったが，これらのパルプシートはいずれも硝酸法パ ルプのような黄かっ色を呈しており, 常法の補正值は Table の值より 3〜5 ポイント高くなった。

さて, 比較のために行った $\mathrm{Mg}$ ベースサルファイ 卜蒸解であるが，ａ）は二成分法と同椂にチップを 1 時間水煮沸し, 予備蒸解なしに 1 時間で $150^{\circ} \mathrm{C}$ に昇 温して 4 時間保持したものである。得られたパルプは 全収率, 精製収率がそれぞれ 55.8\%，44.9\% であっ た。したがってリジェクトは $10.9 \%$ であったが，こ
れらはディスクリファイナーで容易に解繊された。こ の解繊繊維を混ぜた分析パルプのホロセルロース量 $90.8 \%$, リグニン量 $7.7 \%$ とい5化学的組成や白色度 34.8 とい5 值は, 他の針葉樹ケミカルパルプと比較 してもそれほど見劣りするものではない。一方 b ) は， 典型的な易漂白タイプの温度一時間曲線に沿って行っ たものであるが，蒸解に先立ってａ）と同じくチップ の前処理を行っている。この条件では心・辺両材が均 一に繊維化して, スクリーン粕は $4.3 \%$ であった。し かし，a）に比べると精製収率では $2.0 \%$ 高いものの 全収率では $4.6 \%$ 低く, 白色度や紙力は同レベルであ り，このことは $\mathrm{Mg}$ ベースで両材を均一に蒸解しても パルプ品質は向上せず, 全体としての収率低下は免れ ないことを示していよう。すなわち $\mathrm{Mg}$ ベース法でこ のよらな心・辺混合チップからケミカルパルプを製造 するには，a）のような条件で十分である。

$150 \sim 160^{\circ} \mathrm{C}$ の二成分パルプは, 全収率や紙力は $\mathrm{Mg}$ ベース a ) パルプのそれとほとんど変わらないが，精 製収率や白色度は低かった。しかし $135^{\circ} \mathrm{C}$ や $140^{\circ} \mathrm{C}$ の パルプは同等の 精製収率で 全収率は $10 \%$ ほど高く, 裂断長や比破裂強さもやや優れていた。

これらのパルプはまた KP と比較すると, 精製収率 で 2 3\%, 全収率では $20 \%$ 以上も上回るが，紙力は 及ばず裂断長, 比破裂強さは $2 / 3$, 比引裂強さは $1 / 2$ 程度の值であった。

Table 6 に示したアカマツの蒸解でもカラマツと同 様な結果で, 二成分法ではいずれもスクリーン粕の多 いパルプであった。それらのうちで，135 140ㄷ の パルプは高リグニン量で蒸解度は低かったが他のもの より全収率, 精製収率は高く, 紙力でも裂断長, 比破 裂強さが優れており白色度も比較的高かった。

$\mathrm{Mg}$ ベースでも a) の条件でケミカルパルプが得ら れ，b）よりも精製収率は低かったが全収率は高く, 両者の紙力, 白色度にはほとんど差がなかった。すな わちアカマツでも, 心材のパルプ化度の向上はパルプ 品質の向上につながっていなかった。

また, 二成分パルプと $\mathrm{Mg}$ ベース $\mathrm{SP}$ 及び $\mathrm{KP}$ と の比較においても, $135 \sim 140^{\circ} \mathrm{C}$ パルプの 精製収率は クラフトより高いが $\mathrm{Mg}$ ベース a ）と変わらず, 白色 度は KP と SP の中間の值で, 紙力は SP を上回る ものの KP ほどの強さではなかった。

以上の二成分蒸解では, いずれの条件でもスクリー ン粕の多いパルプしか得られず, 紙力も SP 程度で, 高収率で且つ高紙力のパルプ製造といら点ではまだ満 足できるものではなかった。リジェクト量が高いのは, 辺材に比べて心材のパルプ化速度が遅いためであり, 
Table 7 Conditions of $\mathrm{SO}_{2}+\mathrm{MgSO}_{4}$ Cooking including pre-impregnation period.

Amount of Chemicals; $\mathrm{SO}_{2} 32 \%$ and $\mathrm{MgSO}_{4} 24 \%$ based on an ovendry wood

Temp. and Time; $\quad$ room temp. $\underset{1 \mathrm{hr} .}{\longrightarrow} 110^{\circ} \mathrm{C} \underset{\mathrm{c}) \text {. or d). }}{\stackrel{\longrightarrow}{\longrightarrow}} 110^{\circ} \mathrm{C} \underset{1 \mathrm{hr} .}{\longrightarrow} 140{ }^{\circ} \mathrm{C} \underset{6 \mathrm{hrs} .}{\longrightarrow} 140^{\circ} \mathrm{C}$ c). $2 \mathrm{hrs}$, and d). $4 \mathrm{hrs}$.

Liquid to wood ratio $; 1,000 \mathrm{ml} / 200 \mathrm{~g}=5$

Table 8 Pulp yields and Properties obtained by the cookings of larch and red pine carried out under the conditions in Table. 7

\begin{tabular}{|c|c|c|c|c|c|c|c|c|c|c|}
\hline \multirow{2}{*}{ Species } & \multirow{2}{*}{$\begin{array}{l}\text { Preimpre- } \\
\text { gnation }\end{array}$} & \multirow{2}{*}{$\begin{array}{c}\text { Total } \\
\text { yield } \\
(\%)\end{array}$} & \multirow{2}{*}{$\begin{array}{l}\text { Screened } \\
\text { yield } \\
(\%)\end{array}$} & \multicolumn{3}{|c|}{ Chemical Components $(\%)$} & \multirow{2}{*}{$\begin{array}{l}\text { Bright- } \\
\text { ness }\end{array}$} & \multicolumn{3}{|c|}{ Paper Strength } \\
\hline & & & & $\begin{array}{l}\text { Holo- } \\
\text { cellulose }\end{array}$ & Pentosan & Lignin & & $\begin{array}{l}\text { Breaking- } \\
\text { length }(\mathrm{km})\end{array}$ & $\begin{array}{l}\text { Burst } \\
\text { factor }\end{array}$ & $\begin{array}{l}\text { Tear } \\
\text { factor }\end{array}$ \\
\hline \multirow[t]{2}{*}{ larch } & c). & 58.7 & 48.6 & 87.2 & 4.1 & 10.2 & 27.5 & 5.5 & 3.2 & 63 \\
\hline & d). & 53.2 & 49.2 & 90.3 & 4.1 & 8.7 & 29.7 & 5.6 & 3.1 & 66 \\
\hline \multirow[t]{2}{*}{ red pine } & c). & 56.5 & 48.2 & 88.2 & 4.6 & 9.7 & 34.6 & 5.8 & 3.4 & 64 \\
\hline & d). & 52.8 & 49.1 & 90.8 & 4.3 & 8.4 & 35.7 & 5.7 & 3.4 & 67 \\
\hline
\end{tabular}

両材への薬液浸透の差が原因していると考えられる。 したがってより精製収率の高いパルプを得るためには, $\mathrm{Mg}$ ベースb）のように前処理の後, さらに薬液の浸 透期間を設けて，両材の速度差を小さくすることが効 果的と思われる。また, 高紙力といらことを考えた場 合, 先述の結果のように $150 \sim 160^{\circ} \mathrm{C}$ といら温度は適 当ではなく, せいぜい $140^{\circ} \mathrm{C}$ までの温度で蒸解する 方が期待がもてる。

そこで Table 7 に示した条件で蒸解を行い, 結果を

Table 8 に示した。

カラマツでは，c）で得られたパルプの精製収率は $48.6 \%$ で先の二成分パルプのいずれのものより高く,

Table 5 において最高の值であった $\mathrm{Mg}$ ベース b ) や $\mathrm{KP}$ と比べてもそれぞれ $1.7 \%, 6.4 \%$ 上回っていた。 このパルプはスクリーン粕が $10.1 \%$ であったので, これを解繊し, 精製繊維に加えて分析を行ったが, 白 色度や紙力も向上して裂断長や破裂強さは KP とほぼ 同程度の強さとなった。さらに 2 時間予備蒸解を行っ たd）ではスクリーン粕が $4.0 \%$ と減少し，心・辺両 材の均一蒸解といら点では満足すべきものとなった。 しかし，c）に比べて精製収率が $0.6 \%$ ，白色度が 2.2 ポイント増加するだけで全収率は低下し, 紙力は 変わらなかった。このよらに予備的な蒸解を行らこと
は, 精製収率や品質の向上に大きな効果があったが, この期間を 2 時間から 4 時間に延長しても得られるパ ルプには実質的な有利性はなかった。

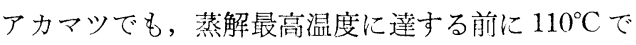
2 あるいは 4 時間保持すると精製収率, 白色度, 紙力 はいずれも向上した。精製収率は, 前者でも $\mathrm{Mg}$ ベー スb）より $0.9 \%, \mathrm{KP}$ より $5.6 \%$, 後者ではそれぞ れ $1.8 \% ， 6.5 \%$ 高く, 紙力も KPをしのぎ, 裂断長, 比破裂強さはKP のそれに匹敵する值であった。しか しながら，カラマツの場合と间様に浸透期間は 2 時間 で十分であり，4 時間ではスクリーン粕が減少するが， 精製繊維収率の増加は小さく品質の向上は見られなか った。

二成分蒸解では，これまではチップの水煮沸処理が 薬液の浸透期間の代用となり，この期間は特に必要が なかった。しかし，本実験のように薬液浸透性にかな りの差がある混合材を均一に蒸解するには水者沸だけ では難があり，両材のパルプ化速度の差をなくすよう な工夫が必要となる。そこでサルファイト法のように 予備蒸解期間を組み入れ, 比較的低温で長時間の蒸解 を行らに至ったが，結果は非常に良好であり，当初の 目的にかなったパルプが得られた。このことはまた， 二成分法では種々の材が混じった雑種チップでも薬液 
の浸透を配慮すれば，均一な蒸解を行らこと が出来, 紙力の高いパルプが得られることを 示していよう。ただし, 予備蒸解は時間を延 長してもパルプの質的问上はそれほど期待出 来ないようなので，嘼当な時間行らべきであ ろら。

\section{2 廃液からの $\mathrm{MgSO}_{4}$ 回収}

試験を行ったのは Table9に示した四種 の針葉樹蒸解廃液で，AとBはそれぞれエゾ マツを $150^{\circ} \mathrm{C}$ で 4 時間, $160^{\circ} \mathrm{C}$ で 3 時間蒸 解したもの，CとDはカラマツとアカマツを ともに $160^{\circ} \mathrm{C}$ で 4 時間蒸解したものである。 薬品量はいずれも $\mathrm{SO}_{2} 32 \%, \mathrm{MgSO}_{4} 24 \%$ (対絶乾木材重量) である。

Table 10 には, おのおのの廃液とパルプ 洗浄液に含まれる $\mathrm{MgSO}_{4}$ 量の测定結果を示 した。な打廃液にも洗液にも $\mathrm{SO}_{2}$ が残留し ており, $\mathrm{BaSO}_{3}$ の生成を防ぐために試料浴
Table 9 Analyses of waste liquors.

\begin{tabular}{|c|l|r|r|r|r|}
\hline initial* & & $\mathrm{A}^{\mathrm{a} .}$ & $\mathrm{B}^{\mathrm{b} .}$ & $\mathrm{C}^{\mathrm{c} .}$ & $\mathrm{D}^{\mathrm{d} .}$ \\
\hline 1,000 & Amount of lipuor (cc) & 990 & 880 & 910 & 900 \\
1.078 & Specfic gravity (20 $)$ & 1.066 & 1.057 & 1.076 & 1.073 \\
1.09 & $\mathrm{pH}\left(20^{\circ}\right)$ & 1.08 & 1.02 & 1.12 & 1.07 \\
6.40 & $\mathrm{SO}_{2}(\%) * *$ & 2.63 & 2.70 & 2.41 & 2.59 \\
64.0 & $\mathrm{SO}_{2}$ (g.) & 23.7 & 23.8 & 21.9 & 23.3 \\
\hline
\end{tabular}

* Amount of $\mathrm{MgSO}_{4}$ was $48.00 \mathrm{~g}$.

** concentration in liquid.

a . from spruce cooking at $150^{\circ} \mathrm{C}-4 \mathrm{hrs}$.

b. from spruce cooking at $160^{\circ} \mathrm{C}-3 \mathrm{hrs}$.

c. from larch cooking at $160^{\circ} \mathrm{C}-4 \mathrm{hrs}$.

d. from red pine cooking at $160^{\circ} \mathrm{C}-4 \mathrm{hrs}$.

Table $10 \mathrm{MgSO}_{4}$ amount in waste liquor and washings for pulp.

\begin{tabular}{|l|c|c|c|c|c|c|c|c|}
\hline & \multicolumn{2}{|c|}{ A } & \multicolumn{2}{|c|}{ B } & \multicolumn{2}{c|}{ C } & \multicolumn{2}{c|}{ D } \\
\hline Kind of liquid & waste & washings & waste & washings & waste & washings & waste & washings \\
sample. cc/total. cc & $10 / 900$ & $50 / 5,000$ & $10 / 880$ & $50 / 5,000$ & $10 / 910$ & $50 / 5,000$ & $10 / 900$ & $50 / 5,000$ \\
coverted $\mathrm{MgSO}_{4}(\mathrm{~g})$ & 0.373 & 0.129 & 0.378 & 0.133 & 0.362 & 0.135 & 0.371 & 0.129 \\
each total $\mathrm{MgSO}_{4}(\mathrm{~g})$ & 33.57 & 12.90 & 33.26 & 13.30 & 32.94 & 13.50 & 33.39 & 12.90 \\
total $\mathrm{MgSO}(\mathrm{g})$ & 46.47 & \multicolumn{2}{|c|}{46.56} & & 46.44 & & 46.29 \\
total/intial*(\%) & 96.82 & \multicolumn{2}{|c|}{97.00} & & 96.76 & 96.42 \\
\hline
\end{tabular}

* initial addition of $\mathrm{MgSO}_{4}=48.00 \mathrm{~g}$.

液を加熱して $\mathrm{SO}_{2}$ を除去してから $\mathrm{BaCl}_{2}$ を加えた。 沪過後の沈殿も希硝酸で十分に洗浄した。

いずれの蒸解でも，廃液と洗液を合わせると最初に 加えた $\mathrm{MgSO}_{4}$ の 96〜97\% が存在しており, 蒸解中 における $\mathrm{MgSO}_{4}$ の消費はないと考えてよい。この うち廃液中の $\mathrm{MgSO}_{4}$ は約 $70 \%$ であったので，以後 はこれらの值を基準として廃液からの回収率を検討し た。

Table 11 には廃液からの濃縮乾固物を炭化した条 件を, Table 12 にはこれらの炭化条件で得られた残 留物を水洗し, $\mathrm{MgSO}_{4}$ を分離回収した值を示した。

また Fig. には, 廃液の濃縮乾固, 炭化, 水洗のそ れぞれの過程で $\mathrm{MgSO}_{4}$ が存在することを確認するた
Table 11 Carbonizing Conditions of material evaporated to dryness from waste liquor.

\begin{tabular}{|c|c|c|c|}
\hline type & $\begin{array}{c}\text { sample weight } \\
(\mathrm{g})\end{array}$ & temperature $\left({ }^{\circ} \mathrm{C}\right)$ & $\begin{array}{c}\text { time } \\
(\mathrm{hr} .)\end{array}$ \\
\hline $\mathrm{a}$ & 2.0 & 350 & 2 \\
$\mathrm{~b}$ & 10.0 & 500 & 2 \\
\hline
\end{tabular}

めに行った X-ray 反射法による回折パターンを示し た。

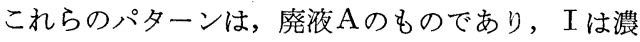
縮乾固物，IIは b) の条件で炭化したもの (未水洗), 
Table 12 Yields of Residues after the Carbonizing Treatment and the Degree of Recovery of $\mathrm{MgSO}_{4}$.

\begin{tabular}{|c|c|c|c|c|c|c|c|c|}
\hline & \multicolumn{2}{|c|}{ A } & \multicolumn{2}{|c|}{ B } & \multicolumn{2}{|c|}{$\mathrm{C}$} & \multicolumn{2}{|c|}{$\mathrm{D}$} \\
\hline $\begin{array}{l}\text { total weight (g) evaporated ma- } \\
\text { terial }\end{array}$ & \multicolumn{2}{|c|}{105.1} & \multicolumn{2}{|c|}{112.2} & \multicolumn{2}{|c|}{115.3} & \multicolumn{2}{|c|}{116.0} \\
\hline Carbonizing Condition & a & $\mathrm{b}$ & a & b & a & $\mathrm{b}$ & a & $\mathrm{b}$ \\
\hline yield $(\%)^{1)}$ & 26.5 & 29.9 & 26.6 & 28.9 & 25.6 & 29.3 & 26.6 & 29.9 \\
\hline $\mathrm{Mg}^{2+}$ in $10 \mathrm{cc}$ washings $(\mathrm{mg})^{2)}$ & 2.690 & 12.383 & 2.620 & 12.984 & 2.522 & 12.001 & 2.303 & 11.036 \\
\hline coverted total $\mathrm{Mg}^{2+}$ in material $(\mathrm{g})$ & 6.775 & 6.550 & 6.884 & 6.483 & 6.958 & 6.376 & 6.632 & 6.377 \\
\hline Degree of Recovery $(\%)^{3)}$ & 70.0 & 64.5 & 71.0 & 66.9 & 71.8 & 65.9 & 68.5 & 65.8 \\
\hline Ratio to reference $(\%)^{4)}$ & 100.1 & 92.2 & 102.4 & 96.5 & 104.6 & 96.0 & 98.5 & 94.6 \\
\hline
\end{tabular}

1) residue weight after washing with water/sample weight $\times 100$

2) calculated from chelate titrimetry.

3) coverted total $\mathrm{Mg}^{2+}$ in material/initial $\mathrm{Mg}^{2+}$ in the cooking liquor $(9.686 \mathrm{~g}) \times 100$

4) total $\mathrm{Mg}^{2+}$ in waste liquor/initial $\mathrm{Mg}^{2+}$ in the cooking liquor $(9.686 \mathrm{~g}) \times 100$ $\mathrm{A} ; 69.9, \mathrm{~B} ; 69.3, \mathrm{C} ; 68.6, \mathrm{D} ; 69.6$

IIIはII の水洗液の一部を湯浴上で蒸発乾固 して得られた白色物質, VIは水洗後の炭化 残留物である。I， II， III とも干渉位置， 強度は異なるが $\mathrm{MgSO}_{4}$ の存在が示され， 純物質の回折值を参考にすると吕々それ゙れ $\mathrm{MgSO}_{4} \cdot \mathrm{H}_{2} \mathrm{O}, \mathrm{MgSO}_{4} \cdot$ anhydrons, $\mathrm{MgSO}_{4}$ . $6 \mathrm{H}_{2} \mathrm{O}$ に相当していた。IV には回折ピー

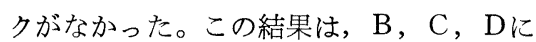
ついても a ) で炭化を行っても同様であり， $\mathrm{MgSO}_{4}$ 以外の物質, 例えば $\mathrm{MgO}$ などは 存在していないと考えられた。またa), b) ぞちらの条件で炭化を行っても残留物の水 洗液は無色透明で, 分光光度計の $430 \mathrm{~nm}$ における透過率は $100 \%$ を示すので有機物 の炭化は完全であった。

しかし, Table 12 に見られるように, $\mathrm{MgSO}_{4}$ の 回収率は $\mathrm{a}$ ) の条件では $\mathrm{A} \sim \mathrm{D}$ のいずれも基準值に対 して $100 \%$ 前後の值で，水洗により $\mathrm{MgSO}_{4}$ が完全に 有機物から分離されたと考えられるのに対して， b ) では 92.2 96.5\% であり，まだ少量が炭化物に付着 していることが分かる。X-ray の測定では，水洗後の 炭化物は $\mathrm{MgSO}_{4}$ の回折をを与えなかったが, これは

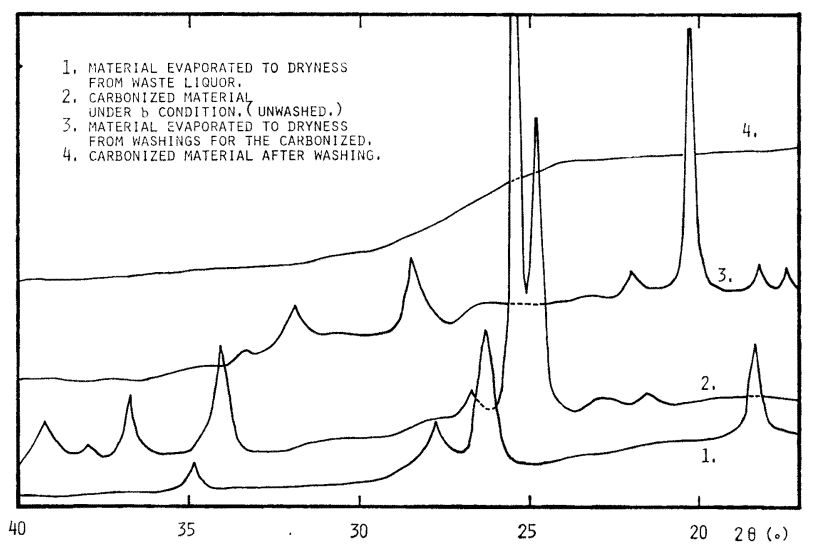

Fig. X-ray Diffraction Patterns of Various Materials.

残留量が非常に少ないためであろう。b ）のものは， その後くり返し水洗浄を行っても回収率は増加しなか った。

このように $\mathrm{MgSO}_{4}$ の回収性は廃液の性質にかかわ りなく, 明らかに炭化条件に関保しており, 炭化残留 物の収量の差,すなわち a) では 25.5 26.5\%, b) では 28.9 29.9\% と a ) の方が $3 \%$ ほど低いことか 
Table 13 Degree of $\mathrm{MgSO}_{4}$ Recovery with washing of $\mathrm{SO}_{2}$ solution subsequent to water.

\begin{tabular}{|c|c|c|c|c|c|c|c|c|}
\hline \multirow[b]{2}{*}{ Carbonizing Condition. } & \multicolumn{2}{|c|}{ A } & \multicolumn{2}{|c|}{ B } & \multicolumn{2}{|c|}{$\mathrm{C}$} & \multicolumn{2}{|c|}{ D } \\
\hline & $\mathrm{a}$ & b & $\mathrm{a}$ & $\mathrm{b}$ & $\mathrm{a}$ & $\mathrm{b}$ & a & b \\
\hline with Water (\%) & 70.0 & 64.5 & 71.0 & 66.9 & 71.8 & 65.9 & 68.5 & 65.8 \\
\hline with $\mathrm{SO}_{2}$ solution 1 st. (\%) & 0.1 & 4.9 & 0.0 & 3.0 & 0.0 & 4.8 & 0.5 & 2.6 \\
\hline 2 nd. (\%) & 0.0 & 0.4 & 0.0 & 0.7 & 0.0 & 0.3 & 0.0 & 0.3 \\
\hline $3 \mathrm{rd} .(\%)$ & $\cdots$ & 0.1 & $\cdots$ & 0.1 & $\cdots$ & 0.1 & $\cdots$ & 0.0 \\
\hline cumulative Recovery (\%) & 70.1 & 69.9 & 71.0 & 70.7 & 71.8 & 71.1 & 69.0 & 68.7 \\
\hline b/a (\%) & $\cdots$ & 99.7 & $\cdots$ & 99.6 & $\cdots$ & 99.0 & $\ldots$ & 99.6 \\
\hline
\end{tabular}

ら示されるように， a ）では有機物の炭化程度が高く, 炭化程度が高ければ $\mathrm{MgSO}_{4}$ はより分離されやすい状 態になると考えられる。

[SO $\mathbf{S O}_{2}$ 水による洗浄〕

上述のように， b ）の条件で有機物を炭化すると， 水洗だけでは $\mathrm{MgSO}_{4}$ を完全に分離回収することが出 来なかった。当研究室の結果倸よる ${ }^{23)}$, 回収率の向 上には $\mathrm{SO}_{2}$ 水による洗浄が効果がある。そこで水洗 後の炭化物を引き続き $\mathrm{SO}_{2}$ 水で洗浄してみた。 $\mathrm{SO}_{2}$ 水の濃度は $1.0 \mathrm{~g} / 100 \mathrm{~m} l$ で 1 回につき $100 \mathrm{cc}$ 用い, 3 回くり返した。また水洗だけで十分上考えられるの ものも，b）との比較のために $\mathrm{SO}_{2}$ 水洗浄を行った。 キレート滴定は, 洗浄液を湯浴上で加熱して $\mathrm{SO}_{2}$ の 臭気がなくなった後, $\mathrm{pH}$ を調整して行った。

結果を Table 13 に示した。

1 回目の $\mathrm{SO}_{2}$ 水洗浄で, b ) のものはいずれも回 收率が増加し, $\mathrm{SO}_{2}$ 水の効果が見られた。この洗浄を 2 3 回くり返すと，a）に対する值は $99 \%$ 以上に達 し, $\mathrm{MgSO}_{4}$ の分離回収はほぼ完全に行われたと考え られる。

a ）の場合, Dでは $0.5 \%$ 溶出して $\mathrm{MgSO}_{4}$ が僅か に残存していたことを示したが，他の $\mathrm{A} ， \mathrm{~B} ， \mathrm{C}$ では $0.0 \sim 0.1 \%$ であり, 予想通り水洗に上る分離忙的 分なかったことが確かめられた。

以上のよらな $\mathrm{MgSO}_{4}$ の回収工程で, その回収率に 影響を与えるのは, 廃液からの濃縮乾固物を炭化する 条件であり， $\mathrm{MgSO}_{4}$ を完全に回収するためには次の 二つのことが要求される。一つは, 有機物の炭化の問 題であり, もし炭化が不十分であれば洗浄液は着色し て有機物と $\mathrm{MgSO}_{4}$ の分離は不可能となる。もう一つ
は，炭化条件が敩しすぎないことである。というのは， 有機物の変化には支障はないが, 炭素の存在下では $\mathrm{Mg} \mathrm{SO}_{4}$ が以下のように分解するからである ${ }^{24)}$ 。

$\mathrm{MgSO}_{4}+\mathrm{C} \longrightarrow \mathrm{MgO}+\mathrm{SO}_{2}+\mathrm{CO}$

この反応の開始温度は約 $750^{\circ} \mathrm{C}$ であるが, 当研究 室では $600^{\circ} \mathrm{C}$ で 2 時間, $700^{\circ} \mathrm{C}$ で 1 時間の処理でも $\mathrm{MgO}$ の生成を認めている。このよ5に $\mathrm{MgSO}_{4}$ が水 難溶性の $\mathrm{MgO}$ に変化することは，水洗の過程を意 味のないものにしてしまい, 同時に $\mathrm{SO}_{2}$ の発生は反 応容器の腐食を促すので, 全く好ましくない。

本実験で採用した a)，b）といら炭化条件はどちら も二つの要求を満たしており，a）では水洗だけ，b) では水と $\mathrm{SO}_{2}$ 水の二段洗浄で廃液中の $\mathrm{MgSO}_{4}$ の 99\%以上が確実に回収された。ただしa）のものでも， 有機成分の炭化物からの分離に万全を期するためには $\mathrm{SO}_{2}$ 水洗浄が必要と思われるので, 実際上の操作は a), b) とも変わらないであろう。

$\mathrm{MgSO}_{4}$ を除去された炭化物は, この後活性化賦活 を受けて活性炭としての能力を与えられることになる。 したがって原料となる炭化物の収率は高い方がよく, 出来るだけ穏やかな条件で炭化を行うことが望ましい が，活性炭の性能は有機物の炭化程度にも依存するの で，最適な炭化条件の設定に関しては活性炭製造の面 からも検討されなければならない。

なお, パルプ洗浄液中に存在する $\mathrm{MgSO}_{4}$ の回収は 行わなかったが, 廃液と同様の行程で定量的に回収で きると思われる。

\section{4. 総 括}

$\mathrm{SO}_{2} 32 \%+\mathrm{MgSO}_{4} 24 \%$ (対木材絶乾重量）の二成 
分蒸解液を用いてカラマツ・アカマツの心材: 辺材 1:1 混合チップを蒸解し, 良質のケミカルパルプが 得られるかどらかを検討して, 次の結果を得た。

1) 両樹種ともに, ケミカルパルプが得られる温度 と時間の関係は, $135 \sim 140^{\circ} \mathrm{C}$ で 6 時間, $150^{\circ} \mathrm{C}$ で 4 時間, $160^{\circ} \mathrm{C}$ で 3 時間であった。

2）得られたパルプはいずれもスクリーン粕が多か ったが,これらのうちでは両樹種とも $135 \sim 140^{\circ} \mathrm{C}$ パ ルプの精製収率, 紙力が高く, $\mathrm{Mg}$ ベース $\mathrm{SP}$ と同等 の精製収率で紙力はより優れていた。しかしKPに比 べると, 精製収率は上回っていたが紙力は劣ってい た。

3） サルファイト法の易漂白型のように, 予備浸透 期間を設けた蒸解では, 両樹種ともスクリーン粕が少 なく精製收率, 白色度, 紙力が向上した。これらのパ ルプの精製収率は $\mathrm{Mg}$ ベース $\mathrm{SP}$ よりも高く, 裂断 長，比破裂強さは KP に匹敵する強さであった。

針葉樹の蒸解廃液から蒸解薬品である $\mathrm{MgSO}_{4}$ の回 収試験を行い，次の結果を得た。

1) $\mathrm{MgSO}_{4}$ は蒸解中に消費されることなく, 廃液 の濃縮乾固, 炭化の行程でも安定に存在していた。

2) $\mathrm{MgSO}_{4}$ の回収性は廃液の性質にかかわらず, 濃縮乾固物を炭化する条件に依存する。

3）有機物の炭化が完全であれば， $\mathrm{MgSO}_{4}$ は完全 に回収できる。ただし，有機物の炭化程度が高いと水 洗浄だけで十分であるが，低い場合は水洗後に $\mathrm{SO}_{2}$ 洗浄を必要とした。

(受理 52.12.26)

\section{参考文 献}

1) H. Exdtman Tappi 33, 486 (1950)

2) S. J. C. Pew Tappi 32, 39 (1949)

3) S. Lagergren et al : Pulp Paper Mag. Can. 60, $\mathrm{T}-338$ (1959)

S. Lagergren et al. : Svensk Papperstidn. 67, 238 (1964)
4) R. Söderquist : papier 11, 487 (1957)

5) I. Croon, B. F. Enström and S. A. Rydholm : Svensk Papperstidn. 67, 196 (1964)

6) O. Nilson and L. Stockman : Svensk Papperstidn. 65, 711 (1962)

7) J. R. G. Bryce and G. H. Tomlinson : Pulp paper Mag. Can. 63, T-355 (1962)

3) E. L. Bailey : Tappi 45, 689 (1962)

9) G. H. Tomlinson et al. : Pulp Paper Meg. Can. 59, No. c' 247 (1958)

10) N. Sanyer and E. L. Keller: Tappi 48, 99 (1965)

11) H. K. van Eyken : Pulp Paper Mag. Can. 65, No. 9, 103 (1964)

12) G. Rowlandson : Pulp Paper Mag. Can. 66, T-65 (1965)

13) H. F. J. Wenzl : Paper Trade J. 149, No. 20, 52 (1965)

14）鈴木 勉, 戸坂圆夫, 林 治助：紙パ技協誌，投 稿中

15）渡辺貞良, 戸坂圆夫 : 紙八技協誌, 25, 103(1971)

16） 戸坂圆夫, 伴内正樹, 林 治助, 渡辺貞良: 紙パ 技協誌, 29,49 (1975)

17）高分子学会編，高分子材料試験法II, p.168 174 共立出版株

18) JIS p. 8123

19) TAPI Standard T-205u-58

20) JIS p. 8210

21) JIS $Z 8701$

22) 久保輝一郎, 加藤誠軌編, X線回折による化学分 析, p. 178 179, 日刊工業新聞社

23）戸坂固夫，未発表

24) R. E. Kisk and D. F. Othmer ed., Encyclopedia of Chemical Technology, Vol. 8, The Interscience Encyclopedia, Inc. New York. 